\title{
СПЕЦИФІКА ТОПОСУ ФІКТИВНОГО МІСТА В РОМАНАХ ЛЮБКА ДЕРЕША
}

Стаття присвячена особливостям художнього конструювання вимишленого міста Мідні Буки в романах українського письменника Л. Дереша. У пропонованому дослідженні місто визначається як топос, якому підпорядковані конкретні просторові одиниці нижчого порядку, що локалізуються в романах «Культ» (2001), «Поклоніння ящірці» (2002) та «Намір!» (2006). Охарактеризовано окремі локуси, систематизовано історію становлення міста. У статті доведено, що місто Мідні Буки позначене наскрізною функціональною диспропорційністю, невідповідністю між сутністю та призначенням, що в просторовому відношенні увиразнюється ізольованістю та наголошенням межового характеру.

Ключові слова: топос, місто, локус, текст, межа.

Творчість Любка Дереша попри відносну новизну має контраверсійну історію прочитання та осмислення. Я. Поліщук зараховує Л. Дереша до покоління митців, які «претендують на ідеологічний меседж молодого покоління, щчо сприймає суспільну дійсність із застереженнями та скепсисом, зате нариисично задивлене у своє приватне життя та нерідко вдається до межових експериментів над власним тілом» [1]. Не зупиняючись детально на літературно-критичній рецепції творчості автора, зауважимо зокрема проблему авторства першого роману як скандальний літературознавчий (чи довколалітературознавчий) дискурс, підтриманий, зокрема, I. Бондарем-Терещенком [2].

Один із аспектів творчості Л. Дереша, що зауважений шанувальниками, проте не осмислений спеціально в літературознавстві, - це деміургічна спроба створити цілком нове місто, Мідні Буки, яке за наявності паралелей в реальному світі постає властивим авторським конструктом. Як зауважує О. Ребрик, «місто, виступає окремим героєм твору, щзо як і инші має свій nрототип» [3]. Будучи «локально-організованим смислотвірним простором» (визначення топосу, дане С. Ляпіним [4]), Мідні Буки постають міжтекстовою реалією, що оприявнена в романах «Культ» (2001), «Поклоніння ящірці» (2002) та «Намір!» (2006). Отож, метою пропонованої 
студії є параметри міського топосу Мідних Буків у романах Л. Дереша. Актуальність студії в обраному ракурсі зумовлена активізацією інтересу до проблеми простору / просторовості у художній творчості як частини загального «просторового повороту» (англ. “spatial turn”) у соціогуманітарному науковому дискурсі (М. Фуко, Г. Башляр, М. де Серто та інші).

Поняття «топос» має риторичне походження, проте в сучасній термінологічній парадигмі воно поступово закріпилося серед просторовочасових параметрів художнього твору. Зокрема, В. Назарець визначає його як «просторово-предметну реалію, яка конщентрує у собі певні семантичноцүіннісні аспекти людського буття» [5]. Такий зміст поняття «топос» має коріння в осмисленні лотманівських «відкритих просторів»; відповідно, 3 «закртими просторами» асоціюється поняття «локус» [6]. Саме такому поняттєвому полі у цій студії оперуватимемо поняттями «локус» і «топос».

«Глибоке читання» (англ. close reading) творів Л. Дереша уможливлює формулювання робочої гіпотези щодо базової характеристики топосу Мідних Буків. Більшість згаданих у трьох романах урбаністичних елементів має одну важливу споріднену ознаку: топос міста наскрізно позначений перехідністю, незавершеністю (недобудовані або зруйновані споруди), диспропорцією призначення та використання його структурних компонентів.

Відповідно, перш ніж перейти до окреслення структури урбаністичного топосу в романах Л. Дереша, слід визначити історію постання міста, оскільки, за М. Анциферовим, місто є культурно-історичним організмом [7], а просторове моделювання в осмисленні міської історії - це тривалий у часі образ відносин людини з осілою місцевістю [8]. О. Галич звертає увагу на рустикальність цього населеного пункту: ««Мідні Буки $\epsilon$ достатньо цивілізоване велике село, де патріархальні звичаї глухих карпатських сіл не дуже nомітні» [9]; цей аспект далі буде врахований та експлікований у цій студії. 
Історія Мідних Буків окреслюється епізодично, проте зі згадок в окремих романах можна скласти відносно цілісну несуперечливу ретроспекцію.

Найраніша історія припадає на невизначені часи австрійського панування в Україні. Показово, що інформація про початки міста оформлюються у фольклоризованому переказі, який переповідає Дзвінка Михайлові («Поклоніння ящірці»). Це типова для міфопоетичної парадигми підміна історії творення історією імені: як зазначає П.Флоренський, у магічній свідомості «річ твориться ім'ям» [10]. Доречно вказати, що за твердженням О. Ткачик «У літературному творі міф імітується $в$ організаиії художньої дійсності» [11], - що й власне спостергаємо у Л. Дереша: відбувається легітимізація міста шляхом імітування цілісної (хоча й суперечливої з точки зору формальної логіки) історії. Слід відзначити, що як друга, так і перша назва поселення є дендронімічною: до розробки покладів село називалося Липинці («Поклоніння Ящірці», с. 52 ${ }^{18}$ ). Як зазначає О. Ребрик, «На Західній Україні й дотепер є село Липиниі, але відомостей про будь-які поклади чого-небудь немає, ходять лише поодинокі легенди. Можливо одна з них і наштовхнула автора на таку інтерпретацію назви» [12].

Переказ Дзвінки має характер підкреслено неконкретної псевдоісторичної нарації про відкриття гірських покладів міді. Початок трансформації села в місто припадає на «тисяча якийсь-там рік» («Поклоніння ящірці», с. 52). Згадку про служіння одного 3 персонажів переказу «при Його Величності королеві Людовику XVII» («Поклоніння ящірці», с. 53), з одного боку, варто розглядати в загальному іронічному контексті Дзвінчиного переказу, особливо 3 огляду на те, що соціальні відносини землевласника й селян характеризуються як «наймитство», а не «кріпацтво»: саме друге було би природно для кінця 18 століття - властивого

\footnotetext{
${ }^{18}$ Роман «Поклоніння ящірці» цитується за виданням: Дереш Л. Поклоніння ящірці / Любко Дереш. - Львів : Кальварія, 2004. - 175 с.; далі в тексті статті у дужках вказуватиметься назва роману та сторінки за цією публікацією.
} 
періоду, у який правив цей король. 3 іншого боку, далі згадується, що до приходу австрійських промисловців постарішали навіть онуки першого власника мідної плавильні Радомира, тож дальша сорокарічна історія експлуатації родовища австрійцями підводить до висновку, що все-таки його відкриття скоріше передувало звільненню селян 1848 року. Таким чином, хронологічні параметри заснування Мідних Буків залишаються затемненими і в інших романах не прояснюються.

Ранній етап заселення просторово не окреслюється, топос у переказі Дзвінки представлений абстрактним палацом пана «Панька», згадкою про село, а також більш деталізованими гірськими елементами (потік, печера, буковий ліс). Із розвитком міста з'являється перша плавильня міді, що належала Радомиру із Пустих Мит. Після вичерпання родовища Мідні Буки перетворилися на гірський курорт. До Першої світової війни поселення стало відпочинковим «спальним містом» («Культ», ${ }^{19}$ ), а пізніше раз по раз переживало періоди збезлюднення. Так, у романі «Культ» згадуються зникнення місцевих мешканців після обох світових війн, вихід завезених на Галичину переселенців зі сходу наприкінці 1940-х, а також масова втеча 1990-х. У романі «Намір!» Петро засвідчує останню подію та конкретизує дату: 1992 рік («Намір!», с. 8-9²0). Також із його розповіді стає відомо, що у 1980-і роки місто почало інтенсивно розбудовуватися, проте будівництва до кінця не довели через брак грошей: «На периферії Мідних Буків (в напрямку левад понад річкою) стояли пусткою ичілі квартали таких недобудов» («Намір!», с. 25).

У 1988 році неподалік від центру міста поставили скульптуру Святої Анни на згадку про жертв НКВС («Поклоніння ящірці», с. 11). У 1992 році місто знелюдніло до такої міри, що було об'єднано дві школи в єдину для всього міста («Намір!», с. 8).

\footnotetext{
${ }^{19}$ Роман «Культ» цитується за джерелом: Дереш Л. Культ [Електронний ресурс] / Любко Дереш. - Режим доступу: www.ukrlit.vn.ua/lib/deresh/3.html; далі в тексті у дужках вказуватиметься назва роману за цією публікацією.

${ }^{20}$ Роман «Намір!» цитується за виданням: Дереш Л. Намір! / Любко Дереш. - К. : ПП Дуліби, 2006. - 296 с.; далі в тексті у дужках вказуватиметься назва роману та сторінки за цією публікацією.
} 
Мідні Буки розташовані в міжгір'ї, що унеможливлює мобільний зв'язок ще на початку 2000-х років: «Мідні Буки з трьох сторін оточені горами, та ще й лежать у природній улоговині» («Культ»). У романі «Поклоніння ящірці» згадується, як виглядає місто згори: «Десь глибоко внизу, у білій димці, розпістерлись, наче сімейка врослих у трунт черепах, наші Мідні Буки, настільки маленькі, що дерева зливалися з хатами. Місто, оточене з трьох сторін горами, мов у захисті мурів» («Поклоніння ящірці», с. 60). Якщо прийняти методику знаходження «душі міста» М. Анциферова (панорамний погляд на топос згори [13] ), то, спираючись на наведені цитати, слід констатувати потаємність душі Мідних Буків, ії закритість для зовнішнього світу.

Заглибленість міста відносно навколишнього ландшафту підсилює його замкнений характер, ізольованість, що на рівні вражень героїв так чи інакше фігурує в різних романах, пов'язується з долями людей.

Показовою $\epsilon$ практично цілковита відсутність традиційних урбаністичних образів, що маркують зв'язок міста з зовнішнім світом: попри згадки про приїзд та від’їзд персонажів залізничний вокзал лише згадується (по одному разу у романі «Культ», «Намір!», жодного разу - у «Поклонінні ящірці»), але не деталізується. Достеменно відомо, що залізницею місто сполучене зі Львовом («Культ») та Тернополем («Намір!»), але сюжетно й просторово образ залізниці у Мідних Буках не виявлений. Цікаво спостерегти, що в романі «Культ» із мінімальною, проте все-таки деталізацією описано прибуття героїв до Жданова: «Банзай $і$ Дощ вийшли на перон - безлюдний (не беручи до уваги горбатого дідуся) $i$ страменно гарячий. Потяг миттю втік, наче боявся довший час залишатися на ціий станціï» («Культ»). Натомість у Мідних Буках такі ситуації переміщення, подорожі відсутні: Банзай одразу по приїзді винаймає квартиру (згадано лише поїзд, а не саме прибуття), гість зі Львова Ростик з'являється вже біля самого коледжу («Культ»); герої, минаючи транспорт, просто щезають із міського простору назавжди (Петро, «Намір!») або на певний час (Гладкий 
Хіппі, «Поклоніння ящірці»). Таким чином, враження ізольованості міста містифікується, поглиблюється на рівні умовчання образів подорожі.

Транспортні засоби як такі в Мідних Буках теж рідкісні: «Автомобілі в центрі, та й узагалі в Мідних Буках, проӥжджали рідше, ніж на вулииях збирався натовп» («Поклоніння ящірці», с. 110).

Ізольованість міста поглиблюється ландшафтними деталями. Так, образ лісу в аналізованих романах неодноразово актуалізується як кінцева межа, завершення міста. Абсолютизовано цю тезу в романі «Поклоніння ящірці»: «Вони мешкають на межі міста й лісу» (тут і далі підкреслення мої, - С. Ц.) («Поклоніння ящірці», с. 6). Подібне семантичне навантаження цього просторового елемента зустрічається в романі «Культ», де хащі служать природним обмеженням поля зору: «Шиби виходили просто на 궀》 («Культ»); «Міст через річку до лісу був вимазаний блідим, холодним медом місячного світла» («Культ»); «Відразу за тим старим будинком - край міста, міст і ліс» («Культ»). У Романі «Намір!» натомість ліс (Вовчухівське лісництво) постає одним із середовищ існування Петра, просторово втілює алієнацію героя: «ходив довкола хати, видивлявся в лісі пояснень своєму незвичному самопочуттю» («Намір!», с. 13); «У ті дні я багато лазив по лісі. ... Так я відволікався від нав'язливих думок про те, щуо не маю в місті ні одної душі, до кого прихилитися...» («Намір!», с. 38); «Добре, щэо я не сварився 3 лісом. Куди би тоді я подався?» («Намір!», с. 39). Таким чином, образ заміського лісу підкреслює вихід Петра поза межі свого урбсу, його відчуженість від «пацанського» середовища у дослідженнях власної унікальності.

У всіх трьох романах просторове помежів'я «місто - ліс» демаркує цивілізацію та позацивілізаційне: у романі «Культ» на рівні глибинного переживання завершення облаштованого всесвіту, у романі «Поклоніння ящірці» - як локалізація позаетичного акту вбивства, у романі «Намір!» пошуку самого себе поза міським середовищем. 
Міські дороги Мідних Буків у романах майже всуціль порожні й безлюдні. Показовим є образ в романі «Поклоніння ящірці»: «Сіра дорога була місиями забарикадована купами бур'яну - в'ялого старого бур'яну, котрий люди лінувались викинути десь у потаємнімому місиі. Подекуди траплялися загадкові розтерті плями: місия страт колорадських жуків, щуо випасалися на нездалій картоплі» («Поклоніння ящірці», с. 39-40). Занедбаність і порожнеча, розмивання міської атрибуції сільською (бур'яни, картопля, жуки) загалом властиві описам Мідних Буків у цьому творі.

У романі «Культ» натомість панує атмосфера «Ідилї-після-чуми» («Культ»): вулиці свіжі й чисті: «Він брів жовтими оранжевими вуличками, дивуючися чистоті алей Паші Ангеліни та Саксаганського, Фрунзе, Дзержинського $і$ Щорса» («Культ»); «порожні акуратні вулички, чисті сквери, безлюдний прибраний парк» («Культ»). Водночас ця чистота підкреслює порожнечу, на що неодноразово звертається увага: «На вулииях міста - ні душі. ... Пахло зимою. І пустка на вулииях» («Культ»); «щзось заповнювало вулищі порожнечею» («Культ»); «Банзай повільно брів порожніми, як після чуми, вулицями» («Культ»). Створюється враження внутрішньої ізоляції міста, потаємності, затемненості. Вибудовується своєрідний емоційно-сугестивний ланцюг: чистота - порожнеча - страх. Ірреальність страху, викликаного безлюддям у місті, 3 плином подій конкретизується відчуттям помежів'я міста з іншим, чужим світом, у якому живе щось чуже й вороже, і саме цей мотив є одним із стрижневих у сюжеті роману.

У романах «Культ» та «Поклоніння ящірці» згадується міський парк. Локус у першому творі представлений епізодично: фігурує осінній пейзаж, акцентовано порожнечу. Натомість у романі «Поклоніння ящірці» помітна увага до химерності, диспропорційності цього локусу. Так, велетенський парк 3 його алеями та лавами виразно невідповідний маленькому місту: «...наче у Мідних Буках жило не дві тисячі, а, скажімо, півмільйона душ, 
котрим ні з того ні з сього припекло посидіти на жорсткому рашпатому дереві» («Поклоніння ящірці», с. 15).

Подібна химерність у співвідношенні сутності й формі стосується образу скульптури святої Анни, яку згадано в романі «Культ» і якій дається більш розгорнута характеристика у творі «Поклоніння ящірці»: «Неподалік від цуентру Мідних Буків, на роздоріжжі, стоїть велика біла скульптура святої Анни, заступниці всіх невинно убієнних, з ледь піднесеними догори, як y Сина, щзо показуе Свої рани, руками» («Поклоніння ящірці», с. 11). Канонічний образ символізує і вшанування річниці християнства (зведена скульптура у 1988 році), і водночас, постає символом пам’яті жертв репресій НКВС. Інша міднобуківська скульптура, яка присвячена вшануванню жертв Другої світової війни («Культ»), абсурдизується (деформується) вже у рецептивному полі: в картині, презентованій аукторіальним наратором [14], статуя доповнюється рисами практики йоги: «поза Ваджрасана», «Аджначакра». Причому впізнавані спостерігачем пози та деталі східної практики контекстуально приписуються задуму: вказано не на схожість, а на суть. Своєрідна реалізація прийому «доповненої реальності», накладання зримого на дійсне вписується загалом у постмодерну іронічну стилістику роману.

Духовні споруди в Мідних Буках згадуються в романі «Культ». На розі вулиць Лисенка і Фрунзе розташувалася православна церква («мала православна цุерковцяя»), позначена диспропорцією форми й змісту вже на рівні екстер’єру: «Ззовні на храмі висіло кілька оголошень», - причому оголошення мають як нейтрально-рекламний характер, так i прямо суперечать сакральній сутності культової споруди (використання обсценної лексики, реклама цілительства тощо). Інтер'єр церковного локусу підсилює перше враження: у храмі ведеться торгівля окультною літературою, белетристикою та порнографією. Вивершується враження внутрішньої диспропорції запаховим контрастивним пуантом: «Хвилею накотився запах кадила і солодкуватий аромат гнилі» («Культ»). 
Подібне враження справляє міський цвинтар, зображений в романі «Поклоніння ящірці»: кладовище постраждало від вандалів, і героями здебільшого використовується як простір відпочинку, своєрідний варіант парку. Михайло називає цвинтар «опозицією Гіацинтовому дому» («Поклоніння ящірці», с. 30): інтуїтивне відчуття «нездоров’я», небезпеки старої будівлі протиставляється вмиротворенню серед могил, хоча зміст вандальських написів споріднює ці локуси.

Топос Мідних Буків у романах Любка Дереша наскрізно сполучає локус інтернату (коледжу). Будівля в романах неодноразово змінює своє призначення, трансформується, причому ця трансформація має в основі як функціональні зміни призначення, так і містичну підоснову: підвали цього приміщення позначені близькістю до іншого всесвіту, де панує чудовисько Йог-Сотот. Адепти цього злого бога перетворили локус інтернату (коледжу) на своєрідний портал між світами (ця колізія частково висвітлюється в романі «Поклоніння ящірці», а також є сюжетотвірною у «Культі»). Таким чином, відбувається розширення простору, поєднання емпіричного хронотопу з містичним.

Будівля коледжу має давню історію: його було засновано за австрійців як готель-пансіонат «Готель де ля Руж» для галицької інтелігенції («Поклоніння ящірці», с. 55), пізніше у ньому обладнали холерник («Поклоніння ящірці», с. 30), потім - інтернат для дівчат («Поклоніння ящірці», с. 6), який до 1996 року стояв напівзруйнований. Період занедбання висвітлений в романі «Поклоніння ящірці», а в романі «Намір!» Петро бере участь у ремонті приміщення під коледж (1997 рік). У ході сюжету «Культу» у цій будівлі працює коледж «Оленяча Шкура». Екстер’єр приміщення не деталізований, відомо, що це чотириповерховий будинок (принаймні, у романі «Культ» найвищий із згаданих поверхів - саме четвертий), розташований «на околииях міста» («Намір!», с. 52), поруч із лісом («Культ»), до нього примикає будівля гуртожитку. 
Назва інтернату «Гіацинтовий Дім», що є конвенційною у спілкуванні героїв «Поклоніння ящірці», виступає однією з численних алюзій творчості Джима Моррісона та гурту “The Doors”; властиво, це назва композиції 3 альбому “L. A. Woman”. Одна 3 ii iнтерпретацій, запропонована Чаком Крісафуллі, спирається на обізнаність Дж. Моррісона з грецькою міфологією: на думку дослідника, поет актуалізував один із сюжетів про переродження, метаморфозу Гіацинта - улюбленця Аполлона [15]. Відповідно, топонім «Гіацинтовий Дім» корелює з долею самої переродженої будівлі, а похмурі конотації, відзначені Ч. Крісафуллі, увиразнюють іï долю в сюжеті романів «Поклоніння ящірці» та «Культ».

Аналізуючи локус інтернату (коледжу) як компонент міського топосу Мідних Буків, слід зауважити, що в романі «Намір!», на відміну від інших двох, відсутній містичний компонент: це звичайне приміщення, що переживає ремонт і перебудову. У «Поклонінні ящірці» акцентується нездорова атмосфера локусу: «Дзвінчина баба казала, шо то недобре місие... Байкам можна й не вірити... Але з Гіацинтовим домом явно було щуось негаразд» («Поклоніння ящірці», с. 31); «Простір особливий. Не такий, як у иілому місті. Такий... інший, ніж у решті місиь... Тонший, чи як? Та, тонкіший» («Поклоніння ящірці», с. 96); «Єдине, у чому я переконався Гіацинтовий Дім місие справді погане. I краще більще туди не заглядати» («Поклоніння ящірці», с. 105). У романі «Культ» містичність будівлі коледжу наростає поступово, поглиблюючи ірраціональний страх, яким охоплене ціле місто. Уперше підвал як частина локусу згадується узагальнено («Страх: рано чи пізно, його починаєш відчувати у цььому місті. ... 3 вогких підвалів та порожніх вулищь» («Культ»)), із накопиченням одкровень головного героя підвал - конкретно підвал коледжу - деталізується як межа світів («у коледжі, в підвалах, там є дуже цікаве місие... воно веде прямісінько на болота Гтха'ата, де існуе в екзилі Йог-Сотот» («Культ»)). У межах сформульованої гіпотези помітним $\epsilon$ ще один рівень функціональної 
диспропорції цих підвалів: вони спершу були переобладнані на дівчачі душові, а пізніше - занедбані.

Переживши низку перетворень, приміщення коледжу виявилося також на помежів ї сакрального і профанного, що поглиблює його диспропорцію на рівні призначення і сутності: місце навчання локалізує перехід між світами та відправну точку у протиборстві «Відкриваючих» і «Закриваючих». На цьому рівні помітна алюзія роману Роджера Желязни «Ніч у самотньому жовтні» («A Night in the Lonesome October», 1993), де відповідне протиборство поставало свого роду багаторівневою грою між утаємниченими. У контексті цієї алюзії цікаво відзначити, що події як гру сприймає Корій - жрець ЙогСотота і сторож «Оленячої Шкури», а відтак - коледж, у тому числі й підвали може інтерпретуватися як гетеротопія (М. Фуко). Функціональна трансформація коледжу у місце зіткнення вічних сил позначається на рівні характеристик локусу (внутрішній простір підвальних коридорів зазнає неприродного розширення, з'являються характерні атрибути містичного локусу: величезна брама, вогняні світильники). Цей простір позбувається реальних координат i конкретної прив'язки до зовнішніх топологічних координат, вписуючись у наскрізний мотив роману - «тотальна дезорієнтація». Н. Ткачик схильна вважати останню версію модифікації підвалів аналогом підземного царства, простором ініціації Юрка Банзая [16]. У результаті кризи гуртожиток руйнується, ховаючи під уламками бетону учнів «Оленячої Шкури». Такий радикальний вияв реалізації функціональної диспропорції $€$ просторовим вираженням кульмінації, руйнуванням створених гетеротопій.

Диспропорції міського топосу Мідних Буків, виявлені на різних рівнях, у всій структурі міської організації закріплені на ієрархічно найвищому рівні невідповідності самому поняттю міста: ізольованість (у просторі, транспортно, у зв’язку тощо), підкреслена рустикальність частини локусів. Легітимізація міста відбувається на рівні конструювання псевдо-історичного міфу про заснування поселення, яке включається в крайову та національну 
історію; паралельно вводиться містичний локальний історичний конструкт (хвилі збезлюднення Мідних Буків). Міжчасовий характер має будівля коледжу, яка в різних романах маркована по-різному. Простір розгортання смислів фіксує помежів'я міста, що також помітно на різних рівнях. Зокрема, топос виявляється рубежем сакрального й профанного («Культ», «Поклоніння ящірці»), рівно як і у просторовому відношенні Мідні Буки акцентуються як маргінес сусідством із лісом, річкою на околиці та горами. Водночас топографія розмічена, спостерігається структура вулиць, що закріплено як назвами, так і описами; визначено центр міста, деталізовані окремі міські локуси, у тому числі - прикметні будівлі. Функціональні диспропорції $є$ наскрізним елементом характеристики окремих складових топосу Мідних Буків, що зміцнює міжтекстову єдність конструювання цілісного урбаністичного простору в трьох романах Любка Дереша.

\section{ЛІТЕРАТУРА}

1. Полішук Я. Простір ідеологічного впливу. До природи репрезентації / Я. Поліщук // Український історичний збірник - 2008. - Вип. 11. - С. 435.

2. Бондар-Терещенко I. Вогонь моїх чресел / Ігор Бондар-Терещенко // Книжникreview. - 2002. - №1 (34). - C. 11.

3. Ребрик $О$. Прототипи художніх образів у творах Любка Дереша [Електронний pecypc] / О. Ребрик. - Режим доступу до публікації : http://www.franko.lviv.ua/faculty/Philol/jaroslov/14/pogljad.html

4. Ляпин C. Концепты и топосы, или Еще один подход к пониманию и преподаванию философии / С. Х. Ляпин // Современные подходы к преподаванию философии. - Архангельск : Изд-во ПомГУ, 1998. - С. 25.

5. Назарещь В. Топос міста в поезії Бертольда Брехта / В. М. Назарець // Вісник Житомирського державного університету імені Івана Франка . - 2013. - Вип. 4. - С. 164.

6. Прокофьева В. Ю. Категория пространства в художественном преломлении: локусы и топосы / В. Ю. Прокофьева // Вестник Оренбургского государственного университета. - 2005. - № 11. - С. 88.

7. Анциферов Н. П. «Непостижимый город...» Душа Петербурга. Петербург Достоевского. Петербург Пушкина / Николай Анциферов ; сост. М. Б. Вербловская. СПб. : Лениздат, 1991. - С. 16.

8. Измайлов А. Пространство города в текстах Н. П. Анциферова / А. Измайлов // История Петербурга. - 2009. - № 6 (52). - С. 7.

9. Галич O. Село і місто в постмодерному тексті / О.А. Галич // Актуальні проблеми слов'янської філології. Серія: Лінгвістика і літературознавство: Міжвуз. зб. наук. ст. - 2010. - Вип. XXIII, ч. 3. - С. 95

10. Флоренский П. Общечеловеческие корни идеализма: [Пробная версия] / Павел Флоренский // Богословский вестник. - 1909. - Т. 1. № 3. - С. 413.

11. Ткачик Н. М. Ініціаційна парадигма міфологічної подорожі героя у міському топосі (на матеріалі романістики Ю. Андруховича) / Н. М. Ткачик // Актуальні проблеми 
слов'янської філології. Серія: Лінгвістика і літературознавство: Міжвуз. зб. наук. ст. 2010. - Вип. XXIII, ч. 1. - С. 296.

12. Ребрик О. Прототипи художніх образів у творах Любка Дереша [Електронний ресурс] / О. Ребрик. - Режим доступу до публікації : http://www.franko.lviv.ua/faculty/Philol/jaroslov/14/pogljad.html

13. Анциферов Н. П. «Непостижимый город...» Душа Петербурга. Петербург Достоевского. Петербург Пушкина / Николай Анциферов ; сост. М. Б. Вербловская. СПб. : Лениздат, 1991. - С. 36.

14. Коваленко $K$. Типи нараторів і види нарації у прозових творах А. П. Чехова («Моє життя», «Розповідь невідомої людини») / Ксенія Коваленко // Філологічні науки. 2012. - Вип. 10. - С. 48.

15. Crisafulli, Chuck, DiMartino, Dave. The Doors: When the Music's Over: The Stories Behind Every Song. - Boston : Da Capo Press, 2000. - P. 135.

16. Ткачик Н. М. Ініціаційна парадигма міфологічної подорожі героя у міському топосі (на матеріалі романістики Ю. Андруховича) / Н. М. Ткачик // Актуальні проблеми слов'янської філології. Серія: Лінгвістика і літературознавство: Міжвуз. зб. наук. ст. 2010. - Вип. XXIII, ч. 1. - С. 296-303.

\section{REFERENCES}

1. Polishchuk Ya. Prostir ideolohichnoho vplyvu. Do pryrody reprezentatsiyi [Space of ideological influence. To the nature of representation], Ukrayins'kyy istorychnyy zbirnyk [Ukrainian historical collection], 2008, No. 11, 435 p [In Ukrainian].

2. Bondar-Tereshchenko I. Vohon' moyikh chresel [The fire of my origins], Knyzhnykreview [Reader-review], 2002, No. 1 (34), p. 11 [In Ukrainian].

3. Rebryk O. Prototypy khudozhnikh obraziv u tvorakh Lyubka Deresha [Prothotypes of heroes in works of Lyubko Deresh], Avaliable in: http://www.franko.lviv.ua/faculty/Philol/jaroslov/14/pogljad.html

4. Lyapin S. Kontsepty i toposy, ili Eshche odin podkhod k ponymaniyu i prepodavaniyu filosofiyi [Concepts and toposes or just one approach to the understanding and teaching of philosophy], Sovremennyye podkhody $k$ prepodavaniyu filosofiyi [Modern approaches to the teaching of philosophy], Arkhanhel'sk, Izd-vo PomHU, 1998, p. 25 [In Russian].

5. Nazarets' $V$. Topos mista $\mathrm{v}$ poeziyi Bertol'da Brekhta [Topos of city in Bertold Brecht's poetry], Visnyk Zhytomyrs'koho derzhavnoho universytetu imeni Ivana Franka [Messenger of Zhytomyr Ivan Franko State University], 2013, No. 4, p. 164 [In Ukrainian].

6. Prokof'eva $V$. Yu. Kategoriya prostranstva v khudozhestvennom prelomleniyi: lokusy i toposy [Space Art Category coverage: topoi and loci], Vestnyk Orenburhskoho hosudarstvennoho unyversyteta [Messenger of Orenburg State University], 2005, No. 11, p. 88 [In Russian].

7. Antsyferov N. P. «Nepostizhymyy gorod...» Dusha Peterburha. Peterburg Dostoevskogo. Peterburg Pushkina [Incomprehensible city. Soul of St. Petersburg. Petersburg of Dostoevsky. Petersburg of Pushkin], Saint-Petersburg, Lenizdat, 1991, p. 16 [In Russian].

8. Izmaylov A. Prostranstvo goroda v tekstakh N. P. Antsyferova [City space in texts of N. P. Antsyferov], Istoriya Peterburga [The history of Petersburg], 2009, No. 6 (52), p. 7 [In Russian]

9. Halych $O$. Selo i misto v postmodernomu teksti [The village and the city in postmodern text] Aktual'ni problemy slov'yans'koyi filolohiyi. Seriya: Linhvistyka $i$ literaturoznavstvo: Mizhvuz. zb. nauk. st. [Actual problems of Slavonic philology: Series: Linguistics and Literary Criticism: Interuniversities collection of scientific works], 2010, Vol. XXIII, No. 3, p. 95 [In Ukrainian].

10. Florenskiy P. Obshchechelovecheskiye korni idealizma [Social origins of idealism], Bohoslovskiy vestnik [Religious messenger], 1909, Vol. 1, No. 3, p. 413 [In Russian]. 
11. Tkachyk N. M. Initsiatsiyna paradyhma mifolohichnoyi podorozhi heroya u mis'komu toposi (na materiali romanistyky Yu. Andrukhovycha) [Initiation paradigm of mythological trip of hero in the city topos (based on the novels of Yu. Andrukhovych)], Aktual'ni problemy slov"yans'koyi filolohiyi. Seriya: Linhvistyka i literaturoznavstvo: Mizhvuz. zb. nauk. st. [Actual problems of Slavonic philology: Series: Linguistics and Literary Criticism: Interuniversities collection of scientific works], 2010, Vol. XXIII, No. 1, p. 296 [In Ukrainian]

12. Rebryk $O$. Prototypy khudozhnikh obraziv u tvorakh Lyubka Deresha [Prothotypes of heroes in works of Lyubko Deresh], Avaliable in: http://www.franko.lviv.ua/faculty/Philol/jaroslov/14/pogljad.html

13. Antsyferov N. P. «Nepostizhymyy gorod...» Dusha Peterburha. Peterburg Dostoevskogo. Peterburg Pushkina [Incomprehensible city. Soul of St. Petersburg. Petersburg of Dostoevsky. Petersburg of Pushkin], Saint-Petersburg, Lenizdat, 1991, p. 36 [In Russian].

14. Kovalenko $K$. Typy naratoriv i vydy naratsiyi u prozovykh tvorakh A. P. Chekhova («Moye zhyttya», «Rozpovid' nevidomoyi lyudyny») [Types of narrators and narrations in epic works of A. P. Chekhov ("My life", "A tale of unknown man")], Filolohichni nauky [Philological studies], 2012, No. 10, p. 48 [In Ukrainian].

15. Crisafulli, Chuck, DiMartino, Dave. The Doors: When the Music's Over: The Stories Behind Every Song, Boston, Da Capo Press, 2000, p. 135 [In English].

16. Tkachyk N. M. Initsiatsiyna paradyhma mifolohichnoyi podorozhi heroya u mis'komu toposi (na materiali romanistyky Yu. Andrukhovycha) [Initiation paradigm of mythological trip of hero in the city topos (based on the novels of Yu. Andrukhovych)], Aktual'ni problemy slov"yans'koyi filolohiyi. Seriya: Linhvistyka i literaturoznavstvo: Mizhvuz. zb. nauk. st. [Actual problems of Slavonic philology: Series: Linguistics and Literary Criticism: Interuniversities collection of scientific works], 2010, Vol. XXIII, No. 1, pp. 296-303 [In Ukrainian]

\title{
АННОТАЦИЯ
}

\section{Сергей Цикавый. Специфика топоса фиктивного города в романах Л. Дереша}

Статья посвящена особенностям художественного конструирования вымышленного города Медные Буки в романах украинского писателя Л. Дереша. В предлагаемом исследовании город определен как топос, которому подчинены конкретные пространственные единицы более низкого порядка, которые локализируются в романах «Культ» (2001), «Поклонение ящерице» (2002) и «Намерение!» (2006). Охарактеризованы отдельные локусы, систематизирована история становления города. В статье доказано, что город Медные Буки отмечен сквозной функциональной диспропорциональностью, несоответствием между сущностью и назначением, что в пространственном отношении усиливается изолированностью и акцентированием пограничного характера.

Ключевые слова: топос, город, локус, текст, граница.

\begin{abstract}
Serhii Tsikavyi. Specifics of fictional town topos in novels by $\mathbf{L}$. Deresh

The article is devoted to the peculiarities of the artistic design of the fictional town Midni Buky in the novels by Ukrainian writer L. Deresh. In the present study the city is defined as a topos, which is a subject to specific spatial units of a lower order, which are localized in the novels "The Cult" (2001), "The Adoration of the lizard" (2002) and "Intent!" (2006). The present article systematized history of the formation of the city. It was observed, that building his own fictional town L. Deresh construct some real stages of legitimation of new settlement: for example, it has its own etiological myth, it has strong ties with local and regional history and it's own mystery (periodical disappearance of inhabitants). We characterized the individual loci, both unique for separate novels and common for all three of them. It was observed that analyzed novels are united with the loci of college (previously - boarding school; deeper in history that building housed hotel, hospital and so on). The loci are certain backspine of the "Midni Buky cycle",
\end{abstract}


differently emphasized in every novel but bearing the clue feature: strong feeling of transitivity, uncertainty. The college building is defined with the wide range of malfunctions: from the edge of worlds to just one of the half-ruined buildings in the city. Some loci of the town are marked by rural features (empty roads, lack of cars, signs of agricultural activity). The town park, unfinished buildings have disproportion of their enormous scale and small population of Midni Buky. The cemetery and church have been vandalized, losing their sacral sense. It was generally concluded that the town of Midni Buky is marked by functional disproportionality, a mismatch between the nature and purpose, that the spatially enhanced with images of isolation and with emphasis on border nature.

Keywords: topos, city, locus, text, border. 